\title{
Identification of Growth-related EST-derived Microsatellite Marker in Nile Tilapia (Oreochromis niloticus)
}

\author{
Sk Md SaeefUlHoque CHISHTY, Piyapong CHOTIPUNTU, \\ Sataporn DIREKBUSARAKOM and Suwit WUTHISUTHIMETHAVEE *
}

\author{
Division of Fisheries Science, School of Agricultural Technology, Walailak University, \\ Nakhon Si Thammarat 80161, Thailand
}

("Corresponding author's e-mail: suwitwuth@gmail.com)

Received: 14 May 2018, Revised: 7 January 2019, Accepted: 2 February 2019

\begin{abstract}
This study aimed at investigating growth-related, EST-derived microsatellite markers in Nile tilapia (O. niloticus). The link between alleles and genotypes of these makers was particularly examined, as well as the growth performances of the samples of offspring produced from the broodstocks of 5 different fishery stations in Thailand. A total of 25 families of offspring were reared to observe the growth performance for a period of 83 days. Fish samples in this study were divided into two categories according to average body weight: fast (+SD) and slow (-SD) growth. Then, the fins of the fish samples were employed to perform DNA analysis. From the fast and slow growth evaluations, 3 families, namely F1, F24 (from Chumphon) and F11 (from Petchaburi), were chosen for the association analysis. A total of 30 fishes with 5 samples from fast and slow growth of each family were utilized. Nineteen EST-derived microsatellite markers were used to genotype 30 DNA samples of the fast and slow growth fishes. Out of 19 loci, 14 loci (i.e., OMO392, OMO051, OMO097, OMO072, OMO327, OMO277, OMO122, OMO193, OMO198, OMO200, OMO335, OMO374, OMO049, and OMO069) were found polymorphic. Another 4 loci (i.e., OMO059, OMO068, OMO315, and OMO337) were observed as monomorphic. Based on the genotype data, there appeared to indicate a strong, significant relationship between allele and growth of the A3 allele of OMO392 locus in the fast growth group. However, no significant genotypes regarding 19 EST-microsatellite were found to be related with growth. This study suggests that the identified allele A3, which has designated the growth hormone related EST-derived microsatellite primer OMO392, can potentially be used to facilitate marker-assisted selection regarding the fast growth of $O$. niloticus.
\end{abstract}

Keyword: EST-derived microsatellite marker, Oreochromis niloticus, Polymorphic loci, Allele, Genotype

\section{Introduction}

Nile tilapia (O. niloticus) has become one of the most important fresh water finfish species in aquaculture [1]. With a global production of about 2.8 million metric tons in 2008 [2], it was estimated to increase to 8.89 million metric tons by the year of 2020 [3]. However, Yue et al. [4] stated that sustainable aquaculture played an important role in transition to a more environmentally and economically viable production by genetic improvement [5]. The production of tilapia has already been under improvement through breeding [6,7]. However, the aquaculture industries of tilapia are still facing the problem of slow growth fish [8]. With the rapid expansion of next-generation sequencing technologies [9], marker-assisted selection and genomic selection are considered as a potential tool to speed up the genetic improvement of tilapia [10,11]. The marker-assisted selection is an effective method in 
http://wjst.wu.ac.th

determining the interested trait, such as growth [12]. It is ideal for various types of applications in tilapia genetics especially in genomic mapping and discovery of QTL [13]. Therefore, their co-dominant in nature, high allelic variation, and polymorphism are indicating imperative for successful growth rate [1416]. Polymorphic DNA markers, such as microsatellites or SNPs (Single Nucleotide Polymorphisms), can be used to analyze the association between markers and traits [17]. Although tandem nucleotide repeats are present in coding regions of the genome most microsatellites markers are neutral or Type II markers [18]. Because of their location in well-conserved regions of the genome, cDNA-derived microsatellites are expected to be conserved in across closely related species and represent a potential source of Type I markers [18]; however, EST-derived microsatellite markers are predicted to be relatively less polymorphic than those derived from genomic DNA [19,20]. In this study, we focused on the growth related EST-derived microsatellites marker in Nile tilapia. We studied the frequency of allele and genotype of microsatellite marker concentrating on the association between these makers and growth related allele and genotype to find a satisfactory way regarding growth based genetic improvement of the fish. This study focused on EST-derived microsatellite marker that was selected in consideration of the criteria of linkage group, species and growth related functions [21]. EST sequences are usually derived from cDNA sequence that are highly polymorphic in nature and play significant part in gene expression, developmental stages and under different environmental conditions [22]. In addition, EST sequences provide crucial information for microarray creation, RNA-sequencing analysis, and genome annotation [23]. It has also been specified that ESTs are useful for high-quality reference-guided assembly of nextgeneration sequencer-generated short reads [24]. Furthermore, it provides a unique idea for understanding of genetic mechanisms [25]. Hagen-Larsen et al. [26] stated that one strategy for identifying the genes expressed in specific life stages and tissues is to use expressed sequence tags or ESTs. These are short stretches of single pass sequences obtained from sequencing cDNA, and are widely used for gene discovery, mapping, polymorphism analysis, expression studies and gene prediction. Gene discovery methods using ESTs include hunting for new members of gene families in the same species (paralogues), for functionally equivalent genes in other species (orthologues), or even for alternatively spliced forms of known genes. ESTs are also used to predict or refine computational predictions of the location of genes in genomic DNA. The aim of this study is to identify growth-related EST-derived microsatellite marker in O. niloticus.

\section{Materials and methods}

\section{Experimental animals}

Brood fish of Nile tilapia (O. niloticus) of Thai strain (GIFT-derived Chitralada 3) were obtained from 5 different fishery stations in Thailand. The stations included Uttaradit, Pathum Thani, Phetchaburi, Buri Ram and Chumphon. The fish were reared in the experimental stations for 4 months to reach the maturation stage. Then, the selection of best male and female pairs with a ratio of 1:1 was conducted to produce 5 family progenies by using single pair mating design crossing. The offspring were primarily reared for 35 days at Chumphon Fishery Station and 60 fry from each family of a total of 25 families were brought to aquaculture laboratory at Walailak University. The fry were, then, grown until they reached the age of 83 days old. The water quality parameters including $\mathrm{pH}$, temperature, and alkalinity were measured and adjusted to obtain the suitable rearing conditions. The monitored $\mathrm{pH}$ was 7.2 to 7.5, temperature was 27 to $30^{\circ} \mathrm{C}$, and alkalinity was $80-100 \mathrm{ppm}$.

\section{Quantitative traits measurements}

The growth performances of Nile tilapia samples from different families were measured in terms of body weight, number of fishes available and survival rate (\%) after culture period. Meanwhile, the final mean weight $(\overline{\mathrm{x}})$ and standard deviation $(\mathrm{SD})$ were analyzed and used as selection criteria to evaluate the fast growth (extremely high growth; $\bar{x}+\mathrm{SD}$ ) and slow growth (extremely less growth; $\overline{\mathrm{x}}-\mathrm{SD}$ ) of each family. However, the number of fish available in each group was also considered as representative families for further DNA analysis. 
http://wjst.wu.ac.th

\section{Sample collection and DNA extraction}

The fin samples of 5 fish from fast and slow growth of each family were collected for DNA isolation and EST-derived microsatellites analysis. Fin tissues were used for DNA extraction following method of Wuthisuthimethavee [27] with some modifications. The quantity and quality of extracted DNA were examined by Spectrophotometers (Thermo Scientific NanoDrop 2000, United States) and $1 \%$ Agarose gel electrophoresis, respectively.

\section{Microsatellite analysis}

The 19 pairs of EST's microsatellite primer were selected based on growth related to the genes from 125 EST's microsatellite primer [21], providing that the level of heterozygosity and good amplification were obtained. The criteria for selection of EST's microsatellite markers include linkage map of chromosome, polymorphic loci, growth trait related functions, information of $O$. niloticus and associated species, number of repeats and flanking region. However, out of 19 pairs of EST sequences, 18 were directly involved with growth regulatory pathways including growth hormone regulatory primer OMO392. On the other hand, OMO337 is to some extent indirectly linked in terms of growth regulatory functions. The polymerase chain reaction was performed in a $10 \mu \mathrm{l}$ reaction volume with a final concentration of $0.2 \mu \mathrm{M}$ forward and reverse primer respectively, 5 x HOT FIREPol ${ }^{\circ}$ (Solis BioDyne, Tartu Estonia) Blend Master Mix, $1 \mu \mathrm{l}$ of DNA template, with nuclease free water was added until the final volume of $10 \mu \mathrm{l}$. The PCR cycling conditions were started with pre-denaturing with a step of $95{ }^{\circ} \mathrm{C}$ for 15 minutes to activate $\mathrm{Taq}$ polymerase. The processes were then followed by 35 cycles of denaturing with a step of 30 seconds at $95{ }^{\circ} \mathrm{C}$, annealing of $30 \mathrm{~s}$ at $50-60{ }^{\circ} \mathrm{C}$ (depending on the $\mathrm{Tm}{ }^{\circ} \mathrm{C}$ of each primer), and extension of 30 seconds at $72{ }^{\circ} \mathrm{C}$. Finally elongation step of $7 \mathrm{~min}$ at $72{ }^{\circ} \mathrm{C}$ of PCR reaction was performed. The PCR products were then visualized on $1 \%$ agarose gel electrophoresis. Electrophoretic separations of amplification of PCR products were performed using polyacrylamide gel electrophoresis and silver staining. The bands representing alleles at the microsatellite loci were scored based on their position and designated as alphabetical order from the bottom to the top of the gel.

\section{Association study between EST-Microsatellite marker and growth}

The associations between each EST-derived microsatellite allele, genotype and growth data were analyzed by using one-way analysis of variance $[28,29]$. The f-value was used to illustrate the variation between sample means and variation within the samples. The p-value was used to determine statistical value on the basis of significance. The level of significant of p-value was used 0.05 as the rejection or acceptance of the association between microsatellite allele and genotype related to growth of Nile tilapia.

\section{Results}

\section{Experimental animals}

At the age of 83 days old, the mean final weight $(\overline{\mathrm{x}})$, standard deviation (SD), number of fishes available for fast and slow growth and survival rate were analyzed as shown in Table 1. From the selection criteria, only 2 families (F1, F11) met the criteria as representative families regarding to the numbers of fish for fast growth and slow growth at least 5 individuals.

In case of F24, the standard deviation was found higher than that of mean that affected the slow growth sample selection. Regarding this issue, no fish was grouped for slow growth of family F24 and the weight lower than $1 \mathrm{~g}$ was potentially selected for family F24 for slow growth. Finally, a total of 30 samples from 3 families of F1, F11 and F24 (5 fish from fast and slow growth) were chosen for DNA analysis and association study. 
http://wjst.wu.ac.th

Table 1 Selection of fast and slow growth of $O$. niloticus samples using final weight (mean and SD), numbers of fish available and survival rates at 83 days old.

\begin{tabular}{|c|c|c|c|c|c|c|c|}
\hline Source & Family & $\begin{array}{c}\text { Final mean } \\
\text { weight }(g)\end{array}$ & SD & $\begin{array}{c}\text { No. of fish } \\
\text { assigned as } \\
\text { Fast }\end{array}$ & $\begin{array}{l}\text { No. of fish } \\
\text { assigned as } \\
\text { Slow }\end{array}$ & $\begin{array}{l}\text { No. of fish at } \\
83 \text { days old }\end{array}$ & $\begin{array}{c}\text { Survival } \\
\text { Rate } \\
(\%)\end{array}$ \\
\hline Chum & $\overline{F_{1}}$ & 5.65 & 4.68 & 8 & 5 & 46 & 95.83 \\
\hline Buri & $\mathrm{F}_{2}$ & 11.03 & 9.48 & 5 & 3 & 36 & 97.30 \\
\hline Utta & $\mathrm{F}_{3}$ & 10.94 & 8.55 & 6 & 4 & 33 & 91.67 \\
\hline Pat & $\mathrm{F}_{4}$ & 7.63 & 8.86 & 3 & 0 & 24 & 68.57 \\
\hline Pat & $\mathrm{F}_{5}$ & 7.42 & 7.56 & 5 & 0 & 31 & 91.18 \\
\hline Chum & $\mathrm{F}_{6}$ & 10.65 & 10.89 & 4 & 0 & 33 & 89.19 \\
\hline Chum & $\mathrm{F}_{7}$ & 8.97 & 10.54 & 5 & 0 & 28 & 73.68 \\
\hline Chum & $\mathrm{F}_{8}$ & 7.51 & 9.14 & 5 & 0 & 23 & 79.31 \\
\hline Pet & $\mathrm{F}_{9}$ & 11.46 & 10.95 & 4 & 0 & 30 & 96.77 \\
\hline Utta & $F_{10}$ & 9.36 & 8.49 & 6 & 2 & 26 & 89.66 \\
\hline Pet & $F_{11}$ & 9.32 & 6.98 & 6 & 8 & 34 & 85.00 \\
\hline Buri & $F_{12}$ & 5.82 & 5.77 & 4 & 0 & 27 & 100.00 \\
\hline Pet & $F_{13}$ & 4.56 & 4.60 & 3 & 0 & 29 & 85.29 \\
\hline Utta & $\mathrm{F}_{14}$ & 4.09 & 4.91 & 2 & 0 & 20 & 68.97 \\
\hline Buri & $\mathrm{F}_{15}$ & 8.14 & 9.51 & 4 & 0 & 25 & 78.13 \\
\hline Chum & $F_{16}$ & 5.83 & 5.05 & 5 & 1 & 31 & 72.09 \\
\hline Chum & $F_{17}$ & 9.25 & 9.07 & 3 & 0 & 17 & 51.52 \\
\hline Pet & $\mathrm{F}_{18}$ & 3.07 & 2.90 & 3 & 0 & 26 & 59.09 \\
\hline Pat & $\mathrm{F}_{19}$ & 3.84 & 3.58 & 4 & 0 & 25 & 73.53 \\
\hline Chum & $\mathrm{F}_{20}$ & 3.41 & 3.33 & 2 & 0 & 29 & 67.44 \\
\hline Utta & $\mathrm{F}_{21}$ & 8.90 & 7.67 & 4 & 2 & 14 & 36.84 \\
\hline Utta & $\mathrm{F}_{22}$ & 7.39 & 6.13 & 5 & 0 & 33 & 64.71 \\
\hline Buri & $\mathrm{F}_{23}$ & 8.24 & 5.41 & 6 & 3 & 45 & 88.24 \\
\hline Chum & $\mathbf{F}_{24}$ & 6.12 & 8.10 & 5 & 0 & 34 & 79.07 \\
\hline Chum & $\mathrm{F}_{25}$ & 6.78 & 5.40 & 6 & 2 & 36 & 75.00 \\
\hline
\end{tabular}

Chum $=$ Chumphon, Buri $=$ Buriram, Utta $=$ Uttaradit, Pat $=$ Patumtanni and Pet $=$ Petchaburi.

PCR amplification

The 27 EST-derived microsatellite primers were screened with Nile tilapia DNA samples. Among them, 19 EST-derived microsatellite were successfully optimized. The size of PCR products varied from 133 to $444 \mathrm{bp}$ and the banding pattern of 2 EST-microsatellite primers, OMO049 and OMO193 having PCR product lengths of $224 \mathrm{bp}$ and $349 \mathrm{bp}$ as shown in Figure 1. 
224 bp

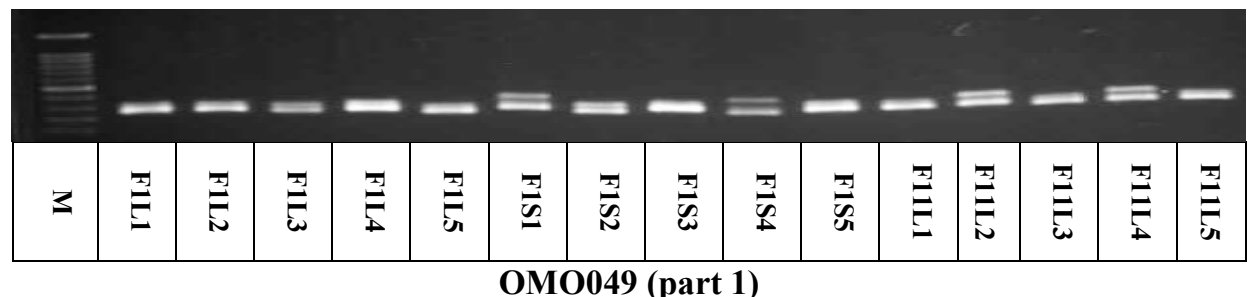

OMO049 (part 1)

224 bp

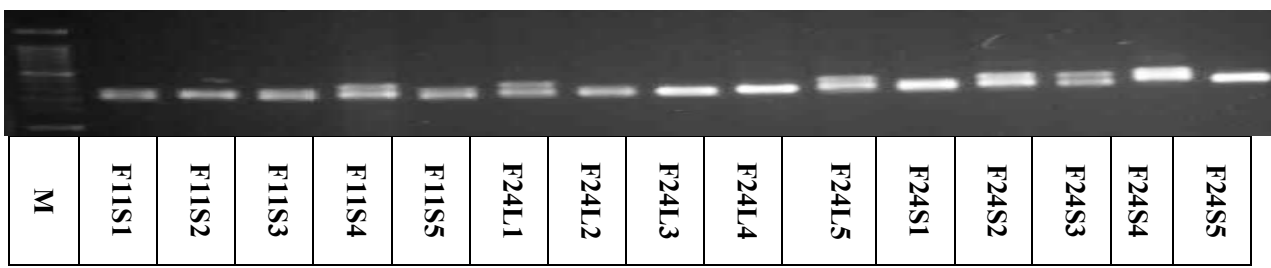

OMO049 (part 2)

349 bp

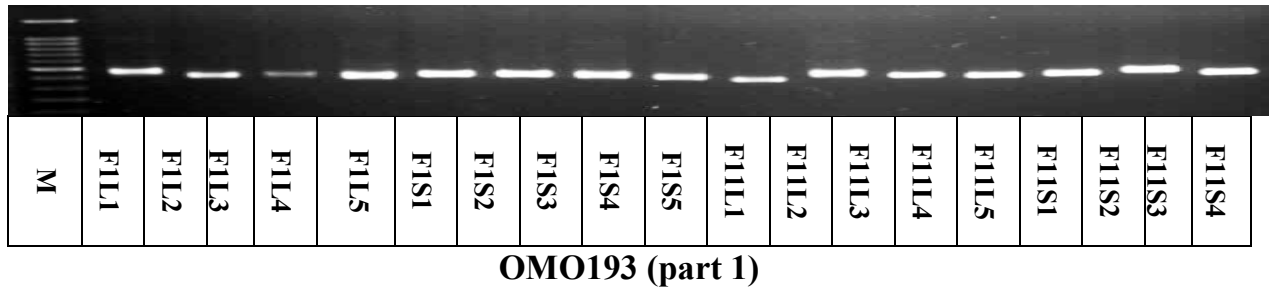

349 bp

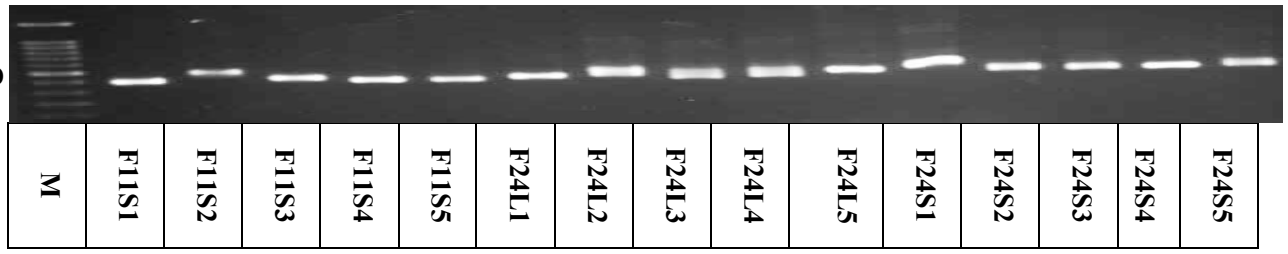

OMO193 (part 2)

Figure 1 PCR amplification products on $1 \%$ agarose gel electrophoresis; OMO049 and OMO193 are EST-derived microsatellite primers, 100 bp DNA ladder (M) and F1L1-F24S5 are DNA of O. niloticus samples. Amplicon sizes are indicated on the left.

\section{Polyacrylamide gel electrophoresis}

Amplified PCR products were then run on $5 \%$ denaturing polyacrylamide gel and subsequent visualization were performed using silver staining methods. Among 19 EST-derived microsatellite primers, 14 loci were resulted in clear banding pattern and visualized through staining. Banding patterns of OMO049 and OMO193 on $5 \%$ denaturing polyacrylamide gel were shown in Figure 2. 
http://wjst.wu.ac.th

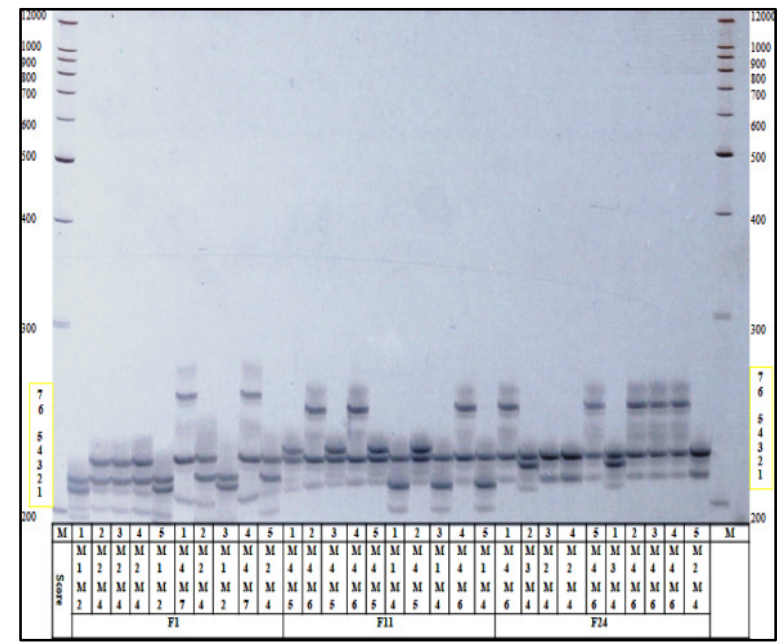

OMO049

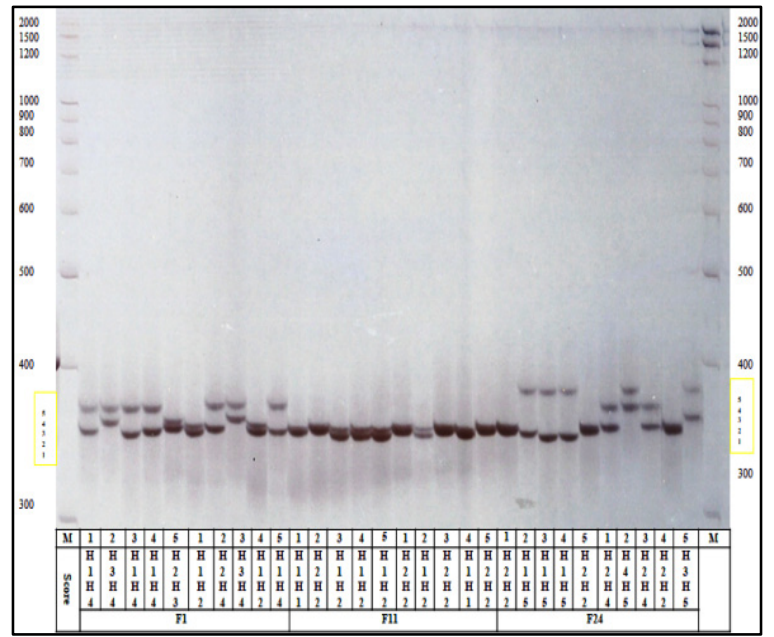

OMO193

Figure 2 Polymorphism of PCR amplification products on $5 \%$ polyacrylamide gel electrophoresis; OMO049 and OMO193 are EST-microsatellite primers, 100 bp DNA ladder (M) and F1L1F24S5 are DNA of $O$. niloticus samples. Amplicon sizes are indicated on the left.

\section{Allele frequency}

A total of 51 alleles were resulted from 14 EST-derived microsatellite loci. The number of allele varied from 2 to 7 (Table 2). The average number of allele in each locus was estimated as 3.65. From allele frequency, 25 alleles leaded to the allele frequency of 0.25 in each locus whereas alleles 10 were estimated as the frequency of less than 0.1. Moreover, the highest number of allele was observed in OMO049 and the lowest numbers of allele were detected in primer OMO198, OMO335 and OMO374. 
http://wjst.wu.ac.th

Table 2 Allele frequency of 14 EST-derived microsatellite primers (allele frequency $\geq 0.25$ were highlighted).

\begin{tabular}{|c|c|c|c|c|c|c|c|}
\hline \multirow{2}{*}{ Primers } & \multicolumn{7}{|c|}{ Number of allele } \\
\hline & 1 & 2 & 3 & 4 & 5 & 6 & 7 \\
\hline OMO392 & 0.130 & 0.310 & 0.560 & & & & \\
\hline OMO051 & 0.084 & 0.500 & 0.250 & 0.166 & & & \\
\hline OMO072 & 0.310 & 0.160 & 0.180 & 0.350 & & & \\
\hline OMO097 & 0.084 & 0.050 & 0.450 & 0.416 & & & \\
\hline OMO327 & 0.200 & 0.250 & 0.050 & 0.400 & 0.100 & & \\
\hline OMO277 & 0.150 & 0.590 & 0.100 & 0.160 & & & \\
\hline OMO122 & 0.817 & 0.016 & 0.167 & & & & \\
\hline OMO193 & 0.283 & 0.400 & 0.067 & 0.167 & 0.083 & & \\
\hline OMO198 & 0.360 & 0.640 & & & & & \\
\hline OMO200 & 0.174 & 0.576 & 0.250 & & & & \\
\hline OMO335 & 0.600 & 0.400 & & & & & \\
\hline OMO374 & 0.570 & 0.430 & & & & & \\
\hline OMO049 & 0.100 & 0.184 & 0.033 & 0.450 & 0.067 & 0.133 & 0.033 \\
\hline OMO069 & 0.184 & 0.400 & 0.416 & & & & \\
\hline
\end{tabular}

\section{Genotype frequency}

The total number of the observed genotype was 79 from 14 EST-derived microsatellite loci. The genotype number was ranged from 3 to 10. The average number of the genotype was estimated to be 5.65. Maximum numbers of genotype were found in OMO327 and OMO193 whereas minimum numbers of genotype were resulted in OMO392, OMO97, OMO198, OMO335 and OMO374 (Table 3).

Table 3 Genotype frequency of 14 polymorphic EST-microsatellite loci.

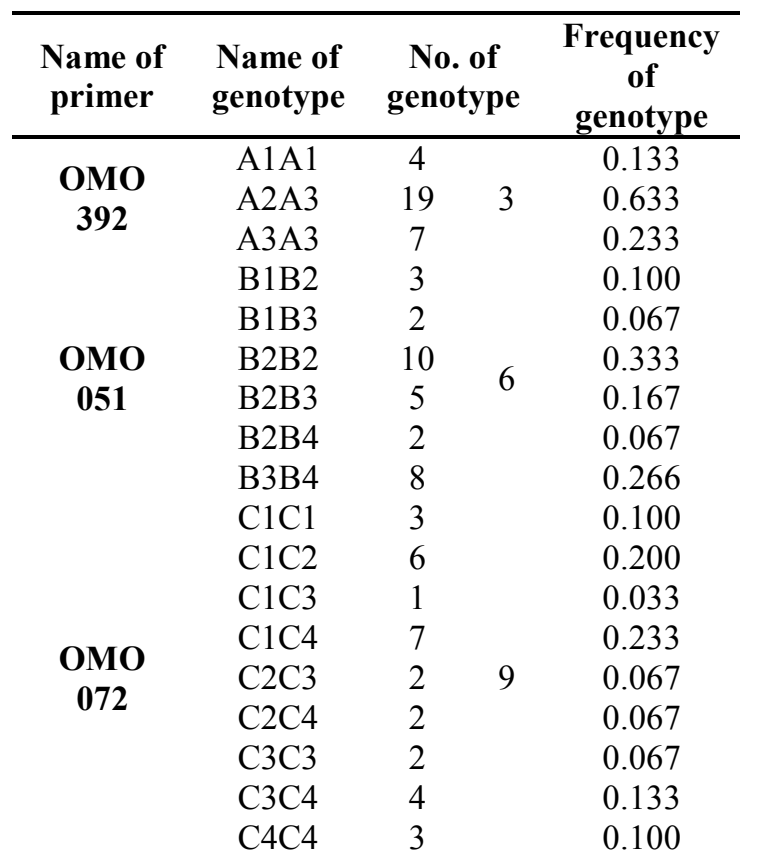

\begin{tabular}{|c|c|c|c|}
\hline $\begin{array}{c}\text { Name } \\
\text { of } \\
\text { primer }\end{array}$ & $\begin{array}{l}\text { Name of } \\
\text { genotype }\end{array}$ & $\begin{array}{c}\text { No. of } \\
\text { genotype }\end{array}$ & $\begin{array}{c}\text { Frequency } \\
\text { of } \\
\text { genotype }\end{array}$ \\
\hline \multirow{10}{*}{$\begin{array}{c}\text { OMO } \\
193\end{array}$} & H1H1 & 2 & 0.067 \\
\hline & $\mathrm{H} 1 \mathrm{H} 2$ & 6 & 0.200 \\
\hline & $\mathrm{H} 1 \mathrm{H} 4$ & 4 & 0.133 \\
\hline & H1H5 & 3 & 0.100 \\
\hline & $\mathrm{H} 2 \mathrm{H} 2$ & 7 & 0.233 \\
\hline & $\mathrm{H} 2 \mathrm{H} 3$ & 1 & 0.033 \\
\hline & $\mathrm{H} 2 \mathrm{H} 4$ & 3 & 0.100 \\
\hline & H3H4 & 2 & 0.067 \\
\hline & Н3H5 & 1 & 0.033 \\
\hline & H4H5 & 1 & 0.033 \\
\hline \multirow{3}{*}{$\begin{array}{c}\text { OMO } \\
198\end{array}$} & I1I1 & 3 & 0.100 \\
\hline & I1I 2 & 16 & 0.533 \\
\hline & $\mathrm{I} 2 \mathrm{I} 2$ & 11 & 0.367 \\
\hline \multirow{5}{*}{$\begin{array}{c}\text { OMO } \\
200\end{array}$} & $\mathrm{~J} 1 \mathrm{~J} 1$ & 3 & 0.115 \\
\hline & $\mathrm{J} 1 \mathrm{~J} 2$ & 1 & 0.038 \\
\hline & $\mathrm{J} 1 \mathrm{~J} 3$ & 2 & 0.077 \\
\hline & $\mathrm{J} 2 \mathrm{~J} 2$ & 12 & 0.462 \\
\hline & $\mathrm{J} 2 \mathrm{~J} 3$ & 5 & 0.192 \\
\hline
\end{tabular}


http://wjst.wu.ac.th

\begin{tabular}{|c|c|c|c|c|c|c|c|c|c|}
\hline \multirow{3}{*}{$\begin{array}{c}\begin{array}{c}\text { Name of } \\
\text { primer }\end{array} \\
\text { OMO }\end{array}$} & \multirow{2}{*}{$\begin{array}{c}\begin{array}{c}\text { Name of } \\
\text { genotype }\end{array} \\
\text { D1D3 }\end{array}$} & \multicolumn{2}{|c|}{$\begin{array}{c}\text { No. of } \\
\text { genotype }\end{array}$} & \multirow{2}{*}{$\begin{array}{c}\begin{array}{c}\text { Frequency } \\
\text { of } \\
\text { genotype }\end{array} \\
0.167\end{array}$} & $\begin{array}{c}\text { Name } \\
\text { of } \\
\text { primer }\end{array}$ & $\begin{array}{l}\text { Name of } \\
\text { genotype }\end{array}$ & \multicolumn{2}{|c|}{$\begin{array}{c}\text { No. of } \\
\text { genotype }\end{array}$} & $\begin{array}{c}\text { Frequency } \\
\text { of } \\
\text { genotype }\end{array}$ \\
\hline & & 5 & & & & J3J3 & 3 & & 0.115 \\
\hline & D2D4 & 3 & 3 & 0.100 & & K1K1 & 14 & & 0.466 \\
\hline & D3D4 & 22 & & 0.733 & OMO & $\mathrm{K} 1 \mathrm{~K} 2$ & 8 & 3 & 0.267 \\
\hline & E1E1 & 1 & & 0.033 & & $\mathrm{~K} 2 \mathrm{~K} 2$ & 8 & & 0.267 \\
\hline & E1E2 & 3 & & 0.100 & & L1L1 & 12 & & 0.400 \\
\hline & E1E4 & 7 & & 0.233 & ОМО & L1L2 & 10 & 3 & 0.333 \\
\hline & E2E2 & 3 & & 0.100 & 374 & L2L2 & 8 & & 0.267 \\
\hline OMO & E2E3 & 1 & & 0.033 & & M1M2 & 3 & & 0.100 \\
\hline 327 & E2E4 & 4 & 10 & 0.133 & & M1M4 & 3 & & 0.100 \\
\hline & E2E5 & 1 & & 0.033 & & M2M4 & 8 & & 0.267 \\
\hline & E3E5 & 2 & & 0.067 & OMO & M3M5 & 2 & 7 & 0.066 \\
\hline & E4E4 & 5 & & 0.167 & & M4M5 & 4 & & 0.133 \\
\hline & E4E5 & 3 & & 0.100 & & M4M6 & 8 & & 0.267 \\
\hline & F1F2 & 2 & & 0.067 & & M4M7 & 2 & & 0.067 \\
\hline & F1F3 & 3 & & 0.100 & & N1N2 & 5 & & 0.167 \\
\hline & F1F4 & 4 & & 0.133 & & N1N3 & 6 & & 0.200 \\
\hline OMO & $\mathrm{F} 2 \mathrm{~F} 2$ & 13 & 7 & 0.433 & OMO & $\mathrm{N} 2 \mathrm{~N} 2$ & 1 & 5 & 0.033 \\
\hline & $\mathrm{F} 2 \mathrm{~F} 3$ & 3 & & 0.100 & 069 & N2N3 & 17 & & 0.567 \\
\hline & $\mathrm{F} 2 \mathrm{~F} 4$ & 4 & & 0.133 & & N3N3 & 1 & & 0.033 \\
\hline & F4F4 & 1 & & 0.033 & & & & & \\
\hline & G1G1 & 20 & & 0.667 & & & & & \\
\hline OMO & G1G2 & 1 & & 0.033 & & & & & \\
\hline 122 & G1G3 & 8 & 4 & 0.267 & & & & & \\
\hline & G3G3 & 1 & & 0.033 & & & & & \\
\hline
\end{tabular}

\section{Allele association}

Out of 51 alleles from 14 polymorphic loci, 25 alleles were used to analyze one-way ANOVA considering the frequency of allele exceeding 0.25 . From them, only 1 significant allele A 3 representing OMO392 was shown association with growth of O. niloticus (Table 4).

Table 425 selected allele associated with growth of $O$. niloticus among 3 different families, f-value represents the comparison of the joint effect of all variables whereas as p-value indicates the level of significant $(\leq 0.05)$.

\begin{tabular}{ccc}
\hline \multirow{2}{*}{ Allele } & \multicolumn{2}{c}{ Growth } \\
\cline { 2 - 3 } & $\mathrm{F}$ & $\mathrm{P}$ \\
\hline A2 & 1.217 & 0.279 \\
A3 & $\mathbf{5 . 2 4 4}$ & $\mathbf{0 . 0 3 0}$ \\
B2 & 0.039 & 0.845 \\
B3 & 0.010 & 0.922 \\
C1 & 0.183 & 0.672 \\
C4 & 0.290 & 0.595 \\
D3 & 0.472 & 0.498 \\
D4 & 0.026 & 0.872 \\
E2 & 1.608 & 0.215 \\
E4 & 0.076 & 0.785 \\
\hline
\end{tabular}


http://wjst.wu.ac.th

\begin{tabular}{ccc}
\hline \multirow{2}{*}{ Allele } & \multicolumn{2}{c}{ Growth } \\
\cline { 2 - 3 } & F & P \\
\hline F2 & 0.639 & 0.431 \\
G1 & 0.852 & 0.364 \\
H1 & 3.438 & 0.074 \\
H2 & 0.830 & 0.370 \\
I1 & 0.041 & 0.840 \\
I2 & 0.620 & 0.438 \\
J2 & 0.418 & 0.523 \\
J3 & 1.895 & 0.180 \\
K1 & 0.068 & 0.796 \\
K2 & 0.091 & 0.766 \\
L1 & 0.011 & 0.918 \\
L2 & 0.486 & 0.492 \\
M4 & 0.071 & 0.792 \\
N2 & 2.736 & 0.109 \\
N3 & 0.004 & 0.947 \\
\hline
\end{tabular}

\section{Genotype association}

Genotype association study was further carried out for 14 polymorphic loci with frequency exceeding 0.25 from a total number of 79 genotypes. Among them, no significant genotype was observed in growth of $O$. niloticus. This suggests that the genotype regarding 19 EST-microsatellite markers are not associated with $O$. niloticus growth.

Table 519 selected genotype associated with growth of $O$. niloticus among 3 different families, f- value represents the comparison of the joint effect of all variables whereas as p-value indicates the level of significant $(\leq 0.05)$.

\begin{tabular}{ccc}
\hline \multirow{2}{*}{ Genotype } & \multicolumn{3}{c}{ Growth } \\
\cline { 2 - 3 } A2A3 & F & P \\
B2B2 & 1.217 & 0.279 \\
B3B4 & 0.097 & 0.757 \\
D3D4 & 0.034 & 0.854 \\
F2F2 & 0.106 & 0.747 \\
G1G1 & 0.128 & 0.723 \\
G1G3 & 0.010 & 0.919 \\
I1I2 & 0.419 & 0.523 \\
I2I2 & 0.074 & 0.787 \\
J2J2 & 0.041 & 0.840 \\
K1K1 & 4.060 & 0.054 \\
K1K2 & 0.091 & 0.766 \\
K2K2 & 0.006 & 0.938 \\
L1L1 & 0.068 & 0.796 \\
L1L2 & 0.486 & 0.492 \\
L2L2 & 0.390 & 0.537 \\
M2M4 & 0.011 & 0.918 \\
M4M6 & 0.002 & 0.961 \\
N2N3 & 0.167 & 0.686 \\
\end{tabular}


http://wjst.wu.ac.th

\section{Identification of EST-Microsatellite Marker}

Out of total 14 polymorphic loci, 1 EST-derived microsatellite marker namely OMO392 was found to be related in terms of significant allelic association. Alternatively, no primer was found to be associated regarding genotypic association with the growth of O. niloticus (Table 5). However, A3 allele of OMO392 was considered specific to fast growth group $(\mathrm{P}<0.05)$ and overall growth of O. niloticus $(\mathrm{P}$ $<0.05)$. That means, OMO392 was further indicated a potential DNA marker for the fast growth of Nile tilapia. On the other hand, it was found insignificant in slow growth group of O. niloticus $(\mathrm{P}>0.05)$. In contrast, genotypic association of 19 genotypes was specified no significant association with growth of $O$. niloticus. Accumulating all allelic and genotypic association, it proposes that, OMO392 can be used effectively for the identification of the fast growth of $O$. niloticus.

\section{Discussion}

We examined 19 EST-derived microsatellite primers with the focus on allelic and genotypic association in relation with growth trait of O. niloticus. Out of 19 loci, it was found that ESTmicrosatellite marker namely OMO392 was associated in terms of significant allelic association. An ESTderived microsatellite locus OMO392 was represented 1 significant allele that is A3, considering fast growth group and growth of Nile tilapia. Yet, it was found insignificant in case of slow growth of Nile tilapia. Then again, genotypic association indicated no significant genotype. However, considering the functions of identified locus OMO392, it contributes the regulation of energy homeostasis resulting from the secretion of GH via pituitary gland. The growth hormones-Insulin-like Growth Factor I is another most important growth axis in fish. In this study, OMO392 has identified as growth hormone related EST-derived microsatellite marker. According to our results, OMO392 indicated significant A3 in both fast and overall growth. It suggests that OMO392 potentially facilitates EST-derived microsatellite assisted selection for improving slow growth. In this regard, a significant association was revealed in growth with a major QTL and GHR2 in tilapia. In contrast, the variations of GH, GHR and other genes in the growth hormone pathway bring about serious abnormal growth identified in fishes [30]. It is therefore discovered that endocrine control of growth and metabolism is interrelated [31]. Loci affecting traits of economic value have been detected and mapped in a variety of livestock species [32]. In other aquaculture species such as Scylla paramamosain, the study found the EST-derived microsatellite marker and their association with the growth performance [33]. A similar trend was found in other aquatic animals such as GIFT in common carp and Japanese scallop. Pereira et al. [34] observed association of GH and IGF-1 polymorphisms with growth traits in synthetic beef cattle breed effects of growth hormone and insulin-like growth factor 1 polymorphisms. Sánchez-Ramos et al. [35] also found significant association between MSTN-1 gene polymorphism and growth traits in gilthead seabream considering the growth hormone, IGF-1, MSTN-1, PRL, and SL genes. An association was also found in MSTN-1 gene polymorphism and growth traits. Velan et al. [36] reported the association between polymorphism in the Prolactin I promoter and growth of tilapia grown in saline water, but no association was observed between the polymorphism in the PRL I promoter and the expression of the gene. Among fish of the similar genus, $O$. mossambicus is considered more salt tolerant than $O$. niloticus in term of the improved growth performance in saline water [37]. Li et al. [38] also focused on the mapping QTL for sex and growth traits in salt-tolerant Tilapia. In salt-tolerant tilapia, different set of genes 'switches' control the growth in males and females. Ma et al. [39] characterized ZFAND3 gene mapped in the sex-determining locus in hybrid tilapia. Manzon [40] found that MSTN-1 was expressed mainly in skeletal muscle, at both adult and juvenile stages, and MSTN-2 was expressed almost exclusively in the central nervous system. An association between this candidate gene and growth is not surprising as myostatin acts as a negative regulator of skeletal muscle growth [41]. Accumulating of all the reviews, it suggests that growth hormone modulatory pathway is associated with allele A3 of EST-derived microsatellite marker OMO392 in O. niloticus. As far as we know, growth traits are quantitative traits and several to numerous genes possibly control them. These genes may have segregated and/or recombined among different generations. Hence, we should investigate the replicability of this marker in different families and 
http://wjst.wu.ac.th

populations, and evaluate the correlation across different generations. This target microsatellite locus will thus be applied for the practical selection of $O$. niloticus for growth performance.

\section{Conclusions}

This study focused on 19 EST-microsatellite primers resulting 14 polymorphic EST-microsatellite loci for $O$. niloticus, and revealed significant $(P<0.05)$ allelic association with growth and fast growth group. As for the association between alleles and growth, allele A3 was found to relate with growth and fast growth group, whereas insignificant association was identified in slow growth group suggesting the EST-microsatellite loci OMO392. On the other hand, from genotypic association, no significant genotypes of the mentioned 14 polymorphic EST-microsatellite loci were found in growth of O. niloticus. It can be concluded that the identified allele A3, which designated the growth hormone related ESTderived microsatellite primer OMO392, can potentially be used to facilitate marker-assisted selection regarding fast growth of $O$. niloticus.

\section{Acknowledgement}

This research was partially supported by the international graduate scholarship program of Walailak University.

\section{References}

[1] AHMM Kamal and GC Mair. Salinity tolerance in superior genotypes of tilapia, O. niloticus, O. mossambicus and their hybrids. Aquaculture 2005; 247, 189-201.

[2] FAO. Food and agricultural organization: Fisheries statistics. Available at: http://www.fao.org/fishery/statistics, accessed May 2010.

[3] AG Tacon and M Metian. Global overview on the use of fishmeal and fish oil in industrially compounded aquafeeds: Trends and future prospects. Aquaculture 2008; 285, 146-58.

[4] GLH Yue and J Li. Tilapia is the fish for next-generation aquaculture. Int. J. Marine Sci. Ocean Technol. 2016; 3, 11-3.

[5] D Cressey. Aquaculture: Future fish. Nature 2009; 458, 398-400.

[6] KM Fitzsimmons. Global tilapia market updates 2015. World Aquaculture Society, Las Vegas, NV: World Aquaculture Society, 2016.

[7] NH Nguyen. Genetic improvement for important farmed aquaculture species with a reference to carp, tilapia and prawns in Asia: Achievements, lessons and challenges. Fish Fish. 2016; 17, 483506.

[8] S Uraiwan. Selective breeding and genetic improvement of Nile tilapia. Thai Fish. Gaz. 1988; 41, 575-80.

[9] ML Metzker. Sequencing technologies-the next generation: Nature reviews. Genetics 2010; 11, 31.

[10] AK Sonesson. Genomic selection for aquaculture: Principles and procedures. In Next generation sequencing and whole genome selection in aquaculture, Wiley-Blackwell, Oxford, UK, 2010.

[11] GH Yue. Recent advances of genome mapping and marker-assisted selection in aquaculture. Fish Fish. 2014; 15, 376-96.

[12] AK Sonesson. Possibilities for marker-assisted selection in fish breeding schemes. In: Proceedings of the International Workshop of Marker Assisted Selection. Food and Agriculture Organization of the United Nations, Turin, Italy, 2003.

[13] RM Al-Atiyat, MJ Tabbaa, NM Salameh, KA Tarawneh, L Al-Shmayla and HJ Al-Tamimie. Analysis of genetic variation of fat tailed-sheep in southern region of Jordan. Asian J. Anim. Vet. Adv. 2012; 7, 376-89.

[14] KT Wada. Genetic selection for shell traits in the Japanese pearl oyster. Aquaculture 1986; 57, 1716.

[15] MV Gupta and BO Acosta. From drawing board to dining table: The success story of the GIFT project. NAGA, World Fish Center Quarterly 2004; 27, 4-14. 
http://wjst.wu.ac.th

[16] MC Saha, MR Mian, I Eujayl, JC Zwonitzer, L Wang and GD May. Tall fescue EST-SSR markers with transferability across several grass species. Theor. Appl. Genet. 2004; 109, 783-91.

[17] L Pannier, RM Hamill, AM Mullen and T Sweeney. Functional genomics approaches to understand the biological pathways underpinning intramuscular fat in beef. CAB Rev. Perspectives Agri. Vet. Sci. Nutr. Nat. Resour. 2010; 5, 1.

[18] SJ O'Brien, JE Womack and LA Lyons. Anchored reference loci for comparative genome mapping in mammals. Nat. Genet. 1993; 3, 103-12.

[19] T Thiel, W Michalek, RK Varshney and A Graner. Exploiting EST databases for the development and characterization of gene-derived SSR-markers in barley (Hordeum vulgare L.). Theor. Appl. Genet. 2003; 106, 411-22.

[20] JR Ellis and JM Burke. EST-SSRs as a resource for population genetic analyses. Heredity 2007; 99, 125-32.

[21] F Liu, FLJ Sun, JH Xia, G Lin, RJ Tu and GH Yue. A microsatellite-based linkage map of salt tolerant tilapia. (O. mossambicus x Oreochromis spp.) and mapping of sex-determining loci. BMC Genom. 2013; 14, 58.

[22] GR Franco, MD Adams, MB Soares, AJ Simpson, JC Venter an SD Pena. Identification of new Schistosomamansoni genes by the EST strategy using a directional cDNA library. Gene 1995; 152, 141-7.

[23] ML Rise, KR von Schalburg, GD Brown, MA Mawer, RH Devlin, N KuipersandP Hunt. Development and application of a salmonid EST database and cDNA microarray: Data mining and interspecific hybridization characteristics. Genom. Res. 2004; 14, 478-90.

[24] S Liu, D Vijayendran and BC Bonning. Next generation sequencing technologies for insect virus discovery. Viruses $2011 ; \mathbf{3}, 1849-69$.

[25] HP Zhu, ZG Liu, MX Lu, FY Gao, XLKe and ZH Huang. Screening and identification of microsatellite markers associated with cold tolerance in Nile tilapia. Genet. Mol. Res. 2015; 14, 10308-14.

[26] H Hagen-Larsen, JK Laerdahl, F Panitz, A Adzhubei and B Høyheim. An EST-based approach for identifying genes expressed in the intestine and gills of pre-smolt Atlantic salmon (Salmo salar). BMC Genom. 2005; 6, 171.

[27] S Wuthisuthimethavee. Master thesis Graduate School, Kasetsart University, Thailand, 1999.

[28] S Dong, J Kong, X Meng, Q Zhang, T Zhang and R Wang. Microsatellite DNA markers associated with resistance to WSSV in Penaeus (Fenneropenaeuschinensis). Aquaculture 2008; 282, 138-41.

[29] X Zheng, YLW Kuang, D Cao and X Sun. Transcriptome-derived EST-SSR markers and their correlations with growth traits in crucian carp. Fish Sci. 2014; 80, 977-84.

[30] F Liu, F Sun, JH Xia, J Li, GH Fu, G Lin, RJ Tu, ZY Wan, D Quek and GH Yuea. A genome scan revealed significant associations of growth traits with a major QTL and GHR2 in tilapia. Sci. Rep. 2014; 4, 7256.

[31] J Pérez-Sánchez and LB Pierre-Yves. Growth hormone axis as marker of nutritional status and growth performance in fish. Aquaculture 1999; 177, 117-28.

[32] L Andersson. Genetic dissection of phenotypic diversity in farm animals. Nat. Rev. Genet. 2001; 2, $130-8$.

[33] H Ma, W Jiang, P Liu, N Feng, Q Ma, C Ma, S Li, Y Liu, Z Qiao and L Ma. Identification of transcriptome-derived microsatellite markers and their association with the growth performance of the mud crab (Scylla paramamosain). PloS One 2014; 9, e89134.

[34] AP Pereira, MMD Alencar, HND Oliveira and LCDA Regitano. Association of GH and IGF-1 polymorphisms with growth traits in a synthetic beef cattle breed. Genet. Mol. Biol. 2005; 28, 2306.

[35] I Sánchez-Ramos, I Cross, J Mácha, G Martínez-Rodríguez, V Krylov and L Rebordinos. Assessment of tools for marker-assisted selection in a marine commercial species: significant association between MSTN-1 gene polymorphism and growth traits. Sci. World J. 2012; 2012, e369802. 
http://wjst.wu.ac.th

[36] A Velan, GHulata, M Ron, T Slosman, A Shirak and A Cnaani. Association between polymorphism in the Prolactin I promoter and growth of tilapia in saline-water. Aquac. Rep. 2015; 1, 5-9.

[37] JT Streelman and TD Kocher. Microsatellite variation associated with prolactin expression and growth of salt-challenged tilapia. Physiol Genom. 2002; 9, 1-4.

[38] CY Li, TY Chiang, YC Chiang, HM Hsu, XJ Ge, CC Huang and KH Hung. Cross-species, amplifiable EST-SSR markers for Amentotaxus species obtained by next-generation sequencing. Molecules 2016; 21, 67.

[39] D Ma, A Ma, Z Huang, G Wang, T Wang, D Xia and B Ma. Transcriptome analysis for identification of genes related to gonad differentiation, growth, immune response and marker discovery in the turbot (Scophthalmusmaximus). PloS One 2016; 11, e0149414.

[40] LA Manzon. The role of prolactin in fish osmoregulation: A review. Gen. Comp. Endocr. 2012; 125, 291-310.

[41] R Fries, R Hanset and M Georges. A deletion in the bovine myostatin gene causes the doublemuscled phenotype in cattle. Nat. Genet. 1997; 17, 71. 